\title{
Predictive Role of Circulating Immune Cell Subtypes Early after Allogeneic Hematopoietic Stem Cell Transplantation in Patients with Acute Leukemia
}

\author{
Tae Woo Kim ${ }^{1}$, Sung-Soo Park ${ }^{1}$, Ji-Young Lim¹, Gi June Min ${ }^{1}$, Silvia Park ${ }^{1}$, \\ Young-Woo Jeon ${ }^{1,2}$, Seung-Ah Yahng ${ }^{3}$, Seung-Hwan Shin ${ }^{4}$, Sung-Eun Lee ${ }^{1,2}$, Jae-Ho Yoon ${ }^{1,2}$, \\ Byung-Sik Cho ${ }^{1,2}$, Ki-Seong Eom ${ }^{1,2}$, Seok Lee ${ }^{1,2}$, Hee-Je Kim ${ }^{1,2}$, Chang-Ki Min ${ }^{1,2}$
}

${ }^{1}$ Department of Hematology, Seoul St. Mary's Hematology Hospital, College of Medicine, The Catholic University of Korea, Seoul, Korea, ${ }^{2}$ Leukemia Research Institute, The Catholic University of Korea, Seoul, Korea, ${ }^{3}$ Department of Hematology, Incheon St. Mary's Hospital, College of Medicine, The Catholic University of Korea, Incheon, Korea, ${ }^{4}$ Department of Hematology, Yeoido St. Mary's Hospital, College of Medicine, The Catholic University of Korea, Seoul, Korea

Background and Objectives: Cells of innate immunity normally recover in the first weeks to months after allogenenic hematopoietic stem cell transplantation (allo-HSCT). Their relevance in terms of graft-versus-host disease (GVHD) and graft-versus-leukemia (GVL) effect is largely unknown. The predictive role of early recovery in the immune cells on acute GVHD and GVL effect after allo-HSCT was investigated in patients with acute leukemia who achieved the first complete remission.

Methods: Peripheral blood samples were taken at the median of 14 days (range, $12 \sim 29$ days) after allo-HSCT. A cohort including 119 samples and characteristics of patients were analyzed. Immune cell populations were identified by flow cytometry.

Results: The median age was 49.0 years (range, $21 \sim 69$ ) at transplantation. Univariate analysis showed that age less than 40 years old, lower frequencies of $\mathrm{CD}^{+} \mathrm{T}$ cells, invariant natural killer $\mathrm{T}$ (iNKT) cells, monocytic myeloid derived suppressor cells (M-MDSCs) and higher frequency of immature MDSCs were associated with occurrence of grade III-IV acute GVHD. Multivariate analyses showed that iNKT cells (hazard ratio (HR), 0.453, 95\% CI, 0.091 0.844, $\mathrm{p}=0.024$ ) and M-MDSCs (HR, 0.271, 95\% CI, 0.078 0.937, $\mathrm{p}=0.039$ ) were independent factors. Combination of higher frequencies of both cell subsets was associated with lower incidence of grade III-IV acute GVHD, whereas patients with lower frequency of iNKT cells and higher frequency of M-MDSCs showed significant higher probability of relapse.

Conclusions: iNKT cells and M-MDSCs could be relevant cell biomarkers for predicting acute GVHD and/or relapse in acute leukemia patients treated with allo-HSCT.

Keywords: Invariant NKT cells, Myeloid-derived suppressor cells, Acute leukemia, Graft-versus-host disease, Graft-versus-leukemia effect, Allogeneic hematopoietic stem cell transplantation

Received: October 15, 2018, Revised: October 15, 2018, Accepted: November 9, 2018, Published online: December 31, 2018

Correspondence to Chang-Ki Min

Department of Hematology, St. Mary's Hematology Hospital, College of Medicine, The Catholic University of Korea, 222 Banpo-daero, Seocho-gu, Seoul 06591, Korea

Tel: +82-2-2258-6054, Fax: +82-2-599-3589, E-mail: ckmin@catholic.ac.kr

(a) This is an open-access article distributed under the terms of the Creative Commons Attribution Non-Commercial License (http://creativecommons.org/licenses/by-nc/4.0/), which permits unrestricted non-commercial use, distribution, and reproduction in any medium, provided the original work is properly cited.

Copyright (c) 2019 by the Korean Society for Stem Cell Research 


\section{Introduction}

Allogeneic hematopoietic stem cell transplantation (allo-HSCT) is an important therapeutic modality for malignancies of hematopoietic origin, some metastatic solid tumors, and a variety of nonmalignant diseases. The most common indications for allo-HSCT are acute leukemias including acute myeloid leukemia (AML) and adult acute lymphoblastic leukemia (ALL) who respond to induction systemic chemotherapy (1). The success of allo-HSCT depends, in large part, on the robust recovery of the lymphoid and myeloid hematopoietic system. A graft-versus-leukemia (GVL) effect gives allo-HSCT superior anti-leukemic activity, with a greater chance of maintaining remission as compared with consolidation chemotherapy (2). However, activated donor $\mathrm{T}$ cells within a distorted antigen-presenting cell (APC) environment in which some host APCs are replaced by donors APCs play a central role in the immunologic attack on host tissues, leading to occurrence of graft-versus-host disease (GVHD), the major complication of allo-HSCT (3). Benefit of GVL effect is limited by greater non-relapse mortality, which can be as high as $20 \% \sim 30 \%$, and the morbidity and mortality associated with GVHD $(4,5)$. A major goal of basic science and translational research has been to develop strategies to reduce the risk of GVHD while maintaining or enhancing GVL effect.

There are shortcomings in the prediction of GVHD and/or GVL effect, indicating the urgent need for non-invasive and reliable laboratory tests to allow tailored preemptive approach based on a precision-medicine strategy. Substantial efforts have been directed towards identifying factors including patient and donor characteristics known before allo-HSCT that are associated with increased relative risk of GVHD. Human leukocyte antigen (HLA) differences between donor and recipient are the major predictors of GVHD (6). Other implicated factors include the indication for transplant $(7)$ patient age $(8,9)$, donor-recipient sex mismatch $(8,9)$, mismatched minor histocompatibility antigens (mHA) in otherwise identical HSCT (10), donor age (11), stem cell source and dose (12), intensity of conditioning, and GVHD prophylaxis $(13,14)$.

While the complexity of immunologic reconstitution is still being unraveled, studies have suggested that early hematopoietic recovery after allo-HSCT can be useful prognostic markers for HSCT outcome (15). To improve outcome predictions in individuals undergoing allo-HSCT in real time, a closer examination of the transplantation immunobiology is necessary. Many factors influencing immune reconstitution after allo-SCT have been identified, including the type of disease, degree of HLA matching between host and donor, recipient age, intensity of previous chemotherapy or the use of radiotherapy, and type and dose of drugs used in the conditioning regimen or GVHD prophylaxis (including $\mathrm{T}$ cell depletion) (16). We reasoned that early expansion of lymphoid and myeloid components is dependent on post-transplant immune environment, in particular, proinflammatory milieu. Therefore, recovery of each immune cell subtype at the time of engraftment might predict the occurrence of GVHD as well as leukemic relapse. To test this hypothesis, we conducted a large retrospective analysis of patients undergoing allo-HSCT for acute leukemia.

\section{Materials and Methods}

\section{Patients and samples}

Between June 2016 and January 2018, data of 157 consecutive adult ( $\geq 18$ years old) patients with acute leukemia who received allo-HSCT at Seoul St. Mary's hospital were retrospectively explored in the study. We excluded patients with following medical conditions: Patients who did not achieve complete remission (CR) before allo-HSCT $(\mathrm{N}=17)$, prior history of non-hematologic malignancy $(\mathrm{N}=4)$, patients who achieved the second $\mathrm{CR}$ after salvage chemotherapy $(\mathrm{N}=12)$, and patients who received post-transplant maintenance therapy $(n=5)$. Therefore, cohort of 119 patients who achieved the first CR before allo-HSCT was constructed. This study was approved by the Institutional Review Board of Seoul St. Mary's hospital and was conducted in accordance with the Declaration of Helsinki. Informed consent was obtained from all patients for being included in the study.

\section{Transplant procedure, GVHD prophylaxis, and supportive care}

Patients received either a myeloablative conditioning (MAC) or a reduced intensity conditioning (RIC) regimen according to treating physician's decision mainly based on disease risk and comorbidities. Conditioning intensity was assessed according to Gyurkocza et al. (17). For GVHD prophylaxis, a calcineurin inhibitor (tacrolimus for unrelated or haploidentical related donor, and cyclosporine for sibling donor) was administered from day -1 in combination with a short-term course of methotrexate (5 $\mathrm{mg} / \mathrm{m}^{2}$ IV bolus on days $+1,+3,+6$, and +11 ). Exceptionally, GVHD prophylaxis in double cord blood transplant group used a combination of tacrolimus and mycophenolate mofetil instead of a short course of methotrexate. During conditioning, antithymocyte globulin 
(ATG, Thymoglobulin ${ }^{\circledR}$, Sanofi Genzyme, Lyon, France) at various doses was infused intravenously into all patients who received stem cells from haploidentical related and a subset of patients who received HSCT from sibling or unrelated donor. Use of ATG and its dose were selected according to the treating physicians' discretions. During transplantation procedures, all patients were treated in a designated room with laminar airflow isolation. Other general supportive care including administration of G-CSF, prophylaxis of veno-occlusive disease, and administration of prophylactic antibiotics was performed as described in our previous reports $(18,19)$.

\section{Identification of immune cell populations from isolated mononuclear cells}

A peripheral blood sample for the analyses of immune cell populations was obtained at the median 14 days (range, 12 29 days) after HSCT. Peripheral blood mononuclear cells (MNCs) were isolated from whole blood (10 $\mathrm{ml}$ ) collected in ETD-coated tubes by Ficoll-Paque density gradient centrifugation and were processed freshly. Forward scatter/Sideward scatter on a log scale was used for gating live cell populations in obtained samples. $\mathrm{CD}^{+}, \mathrm{CD}^{+}$and $\mathrm{CD}^{+}{ }^{+} \mathrm{T}$ cells, $\mathrm{CD}^{+} 6^{+}$cells, natural killer $(\mathrm{NK})$ cells $\left(\mathrm{CD}^{-}{ }^{-} \mathrm{CD}_{56}{ }^{+}\right)$, natural killer T (NKT)-like cells $\left(\mathrm{CD}^{+} \mathrm{CD}^{+} 6^{+}\right)$were analyzed serially by flow cytometry using a LSR Fortessa (BD Biosciences). Regulatory $\mathrm{T}$ cells $\left(\mathrm{CD} 25^{+} \mathrm{CD} 127^{\text {low }}\right.$ in $\mathrm{CD} 3^{+} \mathrm{CD} 4^{+}$cells) and invariant natural killer (iNKT) cells (NKT-like cells marking $\mathrm{V} \beta 11^{+} \mathrm{CD}^{+}$), natural-killer receptor group 2, member D (NKG2D) expression on NK or NKT-like cells and mucosal-associated invariant $\mathrm{T}$ (MAIT, $\mathrm{CD}_{161}{ }^{+} \mathrm{V} \alpha$ $7.2^{+}$in $\mathrm{CD}^{+}$) cells were also analyzed using flow cytometry. Myeloid-derived suppressor cells (MDSCs) were classified into two categories of immature (I-MDSCs) and monocytic (M-MDSCs) as reported previously (20). I-MDSCs were immunophenotyped as the HLA-DR ${ }^{-} \mathrm{Lin}^{-}$

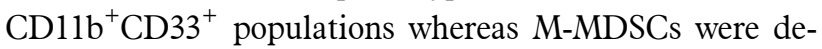
fined as the HLA-DR ${ }^{-} \mathrm{CD} 14^{+}$population. Each subtype of immune cells was quantitated as a percentage of MNCs (Supplementary Fig. 1).

\section{Definition and statistical analyses}

Relapse was defined as the reappearance of leukemic blasts in the peripheral blood (PB) or $\geq 5 \%$ infiltration of a representative bone marrow (BM) smear. Hematopoietic cell transplantation-comorbidity index (HCT-CI) was assessed according to Sorror et al. (21). Acute GVHD were diagnosed and graded according to recent consensus criteria (22). Overall survival (OS) was defined as the time from transplant to death from any cause or date of the last follow-up. Events for disease-free survival (DFS) were relapse or death. OS and DFS rates were calculated using the Kaplan-Meier method and compared using log-rank test. Treatment-related mortality (TRM) was defined as death from any cause during continuous remission. Probabilities of relapse and TRM rates were calculated by cumulative incidence estimation treating non-relapse deaths and relapse as competing risks, respectively. Cumulative incidence of GVHD was estimated considering competing risks including treating deaths, relapse, donor lymphocyte infusion, and graft failure. These cumulative incidences were compared using the Gray test. To determine the significant cut-off level for each variable of immune cell population for GVHD prediction, receiver operating characteristic (ROC) curves were generated. For confirming factors predicting development of acute grade III-IV GVHD, variables with $\mathrm{p}<0.1$ in univariate analyses were entered into multivariate models with an exception for factor of donor type (sibling, unrelated, and haploidentical related). Finally, variables with $\mathrm{p}<0.1$ and factor of donor type regardless of p-value were included in multivariate models using a backward stepwise model selection. All statistical analyses were conducted using R.3.1.1 statistical software (http://cran.r-progect.org/).

\section{Results}

\section{Patients' characteristics}

The median age of patients at HSCT was 49.0 years (range, 21 to 69 years). We identified $74(62.2 \%)$ of AML, $44(37.8 \%)$ of ALL, $1(0.8 \%)$ of mixed phenotype of acute leukemia. Stem cells were collected from 48 (40.3\%) of matched sibling, 40 (33.6\%) of unrelated, 23 (19.3\%) of haploidentical related, and $8(7.6 \%)$ of double cord donor. Except for HSCT using double cord blood, donor source included $93(78.2 \%)$ of peripheral blood and $18(15.1 \%)$ of bone marrow. ATG was administered in 77 (64.7\%) patients with median dose of $2.5 \mathrm{mg} / \mathrm{kg}$ (range, $1.25 \sim 10$ $\mathrm{mg} / \mathrm{kg}$ ). Regarding post-transplant immune populations, median frequencies of $\mathrm{CD}^{+} \mathrm{T}$ cells, iNKT cells, I-MDSCs, and M-MDSCs per MNCs were observed as $14.3 \%$ (range, $0.002 \sim 54.0$ ), $0.061 \%$ (range, $0.0 \sim 8.805$ ), $0.258 \%$ (range, $0.009 \sim 13.4$ ) and $0.109 \%$ (range, $0.004 \sim$ $4.325)$, respectively. Other data of clinical characteristics and post-transplant immune cell populations are summarized in Table 1.

\section{Survival and acute GVHD outcomes}

After a median follow-up of 9.2 months (range, 1.2 
Table 1. Patient characteristics

\begin{tabular}{|c|c|}
\hline Variables & Total patient $(\mathrm{N}=119)$ \\
\hline Median patient's age at transplant, years (range) & $46(21 \sim 69)$ \\
\hline Median donor's age, years (range) & $35(14 \sim 63)$ \\
\hline Gender of patient, male $(\mathrm{N}, \%)$ & $61(51.3)$ \\
\hline Gender of donor, male (N, \%) & $83(69.7)$ \\
\hline Female to male transplant $(\mathrm{N}, \%)$ & $19(16.0)$ \\
\hline Not available to evaluate (heterogeneous sex in double cord donor) $(\mathrm{N}, \%)$ & $5(4.2)$ \\
\hline \multicolumn{2}{|l|}{ Diagnosis } \\
\hline Acute myeloid leukemia (N, \%) & $74(62.2)$ \\
\hline Acute lymphoblastic leukemia $(\mathrm{N}, \%)$ & $44(37.8)$ \\
\hline Mixed phenotype acute leukemia $(\mathrm{N}, \%)$ & $1(0.8)$ \\
\hline \multicolumn{2}{|l|}{ Donor type } \\
\hline HLA-well matched sibling $(\mathrm{N}, \%)$ & $48(40.3)$ \\
\hline HLA-well matched unrelated $(\mathrm{N}, \%)$ & $37(31.1)$ \\
\hline HLA-partial matched unrelated $(\mathrm{N}, \%)$ & $3(2.5)$ \\
\hline Haploidentical related $(\mathrm{N}, \%)$ & $23(19.3)$ \\
\hline Double cord $(\mathrm{N}, \%)$ & $8(7.6)$ \\
\hline \multicolumn{2}{|l|}{ Donor source } \\
\hline Peripheral blood & $93(78.2)$ \\
\hline Bone marrow & $18(15.1)$ \\
\hline Cord blood & $8(6.7)$ \\
\hline \multicolumn{2}{|l|}{ Comorbidity (HCT-Cl*) } \\
\hline Low to intermediate $($ score $<3)(\mathrm{N}, \%)$ & $81(68.1)$ \\
\hline High $($ score $\geq 3)(\mathrm{N}, \%)$ & $38(31.9)$ \\
\hline \multicolumn{2}{|l|}{ Conditioning intensity } \\
\hline Myeloablative conditioning $(\mathrm{N}, \%)$ & $84(70.6)$ \\
\hline Total body irradiation 1320 cGy + cyclophosphamide 120 mg/kg & $57(47.9)$ \\
\hline Total body irradiation $1200 \mathrm{cGy}+$ fludarabine $150 \mathrm{mg} / \mathrm{m}^{2}+$ cytaratbine $9.0 \mathrm{mg} / \mathrm{m}^{2}$ & $7(5.9)$ \\
\hline Fludarabine $150 \mathrm{mg} / \mathrm{m}^{2}+$ busulfex $9.6 \mathrm{mg} / \mathrm{kg}$ & $14(11.8)$ \\
\hline Busulfex $(12.8 \mathrm{mg} / \mathrm{kg})+$ cyclophosphamide $120 \mathrm{mg} / \mathrm{kg}$ & $6(5.0)$ \\
\hline Reduced intensity conditioning $(\mathrm{N}, \%)$ & $35(29.4)$ \\
\hline Total body irradiation $800 \mathrm{cGy}+$ fludarabine $150 \mathrm{mg} / \mathrm{m}^{2}+$ busulfex $6.4 \mathrm{mg} / \mathrm{kg}$ & $19(16.0)$ \\
\hline Total body irradiation $800 \mathrm{cGy}+$ fludarabine $150 \mathrm{mg} / \mathrm{m}^{2}+$ cytaratbine $9.0 \mathrm{mg} / \mathrm{m}^{2}$ & $1(0.8)$ \\
\hline Total body irradiation 400 cGy+fludarabine $150 \mathrm{mg} / \mathrm{m}^{2}+$ busulfex $6.4 \mathrm{mg} / \mathrm{kg}$ & $12(10.1)$ \\
\hline Fludarabine $150 \mathrm{mg} / \mathrm{m}^{2}+$ busulfex $6.4 \mathrm{mg} / \mathrm{kg}$ & $3(2.5)$ \\
\hline \multicolumn{2}{|l|}{ Antithymocyte globulin } \\
\hline None & $42(35.3)$ \\
\hline $1.25 \sim 2.5 \mathrm{mg} / \mathrm{kg}$ & $46(38.7)$ \\
\hline $5.0 \sim 10.0 \mathrm{mg} / \mathrm{kg}$ & $31(26.1)$ \\
\hline Median infused donor $\mathrm{CD} 34^{+}$Cells at $\mathrm{HSCT}, \times 10^{6} / \mathrm{kg}$ (range) & $5.7(0.1 \sim 21.1)$ \\
\hline Median infused donor $\mathrm{CD}^{+}$Cells at $\mathrm{HSCT}, \times 10^{6} / \mathrm{kg}$ (range) & $339.9(2.9 \sim 901.4)$ \\
\hline \multicolumn{2}{|l|}{ Graft-versus-host disease prophylaxis } \\
\hline Methotrexate + cyclosporine & $45(37.8)$ \\
\hline Methotrexate + tacrolimus & $66(55.5)$ \\
\hline Mycophenolate mofetil + tacrolimus & $8(6.7)$ \\
\hline \multicolumn{2}{|l|}{ Post-transplant immune cell population, median frequency, \%/MNC (range) } \\
\hline $\mathrm{CD} 3+\mathrm{T}$ cells, $\mathrm{N}=117$ & $26.8(0.218 \sim 88.3)$ \\
\hline $\mathrm{CD} 4+\mathrm{T}$ cells, $\mathrm{N}=119$ & $4.39(0.002 \sim 54.0)$ \\
\hline CD8 $+\mathrm{T}$ cells, $\mathrm{N}=119$ & $14.3(0.107 \sim 56.7)$ \\
\hline CD56+cells, $N=117$ & $4.757(0.0 \sim 28.002)$ \\
\hline Natural killer cells $\left(\mathrm{CD}^{-}{ }^{-} \mathrm{CD} 56^{+}\right), \mathrm{N}=117$ & $8.1(0.0 \sim 62.0)$ \\
\hline
\end{tabular}


Table 1. Continued

\begin{tabular}{lr}
\hline \multicolumn{1}{c}{ Variables } & Total patient $(\mathrm{N}=119)$ \\
\hline NKT-like cells $\left(\mathrm{CD}^{+}{ }^{+} \mathrm{CD} 56^{+}\right), \mathrm{N}=117$ & $2.63(0.004 \sim 20.6)$ \\
Regulatory T cells $\left(\mathrm{CD} 25^{+} \mathrm{CD} 127^{\text {low }}\right.$ in $\mathrm{CD}^{+} \mathrm{CD}^{+}$cells), $\mathrm{N}=76$ & $0.898(0.0 \sim 22.996)$ \\
invariant NKT cells (iNKT cells, $\left.\mathrm{V} \beta 11^{+} \mathrm{CD}^{+}\right), \mathrm{N}=117$ & $0.061(0.0 \sim 8.805)$ \\
NKG2D expression on NK cells, $\mathrm{N}=117$ & $5.617(0.025 \sim 40.906)$ \\
NKG2D expression on NKT-like cells, $\mathrm{N}=117$ & $1.182(0.0 \sim 11.921)$ \\
MAIT cells $\left(\mathrm{CD} 8^{+} \mathrm{CD} 161^{+} \mathrm{V} \alpha 7.2^{+}\right), \mathrm{N}=119$ & $0.429(0.003 \sim 1.701)$ \\
G-MDSC (HLA-DR $\left.{ }^{-} \mathrm{LIN}^{-} \mathrm{CD} 11 \mathrm{~b}^{+} \mathrm{CD} 33^{+}\right), \mathrm{N}=119$ & $0.258(0.009 \sim 13.4)$ \\
M-MDSC (HLA-DR $\left.{ }^{-} \mathrm{CD} 14^{+}\right), \mathrm{N}=119$ & $0.109(0.004 \sim 4.325)$ \\
\hline
\end{tabular}

HCT-Cl: hematopoietic cell transplantation-comorbidity index, HSCT: hematopoietic stem cell transplantation, MNC: mononuclear cell, NKT: natural killer T cell, NKG2D: natural killer group 2, member D, MAIT: mucosal associated invariant T cell, MDSC: myeloid-derived suppressor cell.

*HCT-Cl was defined by Sorror et al. (21).

Table 2. Multivariate analysis to identify factors affecting grade III-IV acute GVHD

\begin{tabular}{lll}
\hline \multicolumn{1}{c}{ Variables } & \multicolumn{1}{c}{ Grade III-IV acute GVHD } \\
\cline { 2 - 2 } Patient age (years, $<40$ vs. $\geq 40)$ & HR $(95 \%$ Cl) & 0.076 \\
Donor type (sibling, unrelated, haploidentical related, double cord) & $0.378(0.129 \sim 1.109)$ & 0.81 \\
Post-HSCT CD8+ T cells $\% / M N C s, \leq 5.8$ vs. $>5.8)$ & $0.909(0.41 \sim 2.012)$ & 0.19 \\
Post-HSCT iNKT cells $\% / M N C s, \leq 0.027$ vs. $>0.027)$ & $0.453(0.139 \sim 1.41)$ & 0.024 \\
Post-HSCT I-MDSCs (\%/MNCs, $\leq 0.11$ vs. $>0.11)$ & $0.277(0.091 \sim 0.844)$ & 0.091 \\
Post-HSCT M-MDSCs $\% / M N C, \leq 0.27$ vs. $>0.27)$ & $2.825(0.848 \sim 9.417)$ & 0.039 \\
\hline
\end{tabular}

GVHD: graft-versus-host disease, HSCT: hematopoietic stem cell transplantation, MNCs: mononuclear cells, iNKT cells: invariant natural killer cells, I-MDSCs: immature myeloid-derived suppressor cells, M-MDSCs: monocytic myeloid-derived suppressor cells.

24.9 months) for survivors, estimated OS and DFS rates at 1 years were $87.3 \%$ (95\% CI, 78.5 92.7) and $83.8 \%$ (95\% CI, 74.6 89.9), respectively. One-year cumulative incidences of relapse and TRM were $8.7 \%$ (95\% CI, 4.2 15.4) and $7.4 \% \quad(95 \% \quad \mathrm{CI}, \quad 3.2 \sim 14.1)$, respectively (Supplementary Fig. 2). 180-day cumulative incidences of grades II $\sim$ IV and grade III $\sim$ IV acute GVHD were $35.4 \%$ (95\% CI, 26.8 44.0) and 10.9\% (95\% CI, 6.1 17.3), respectively (Supplementary Fig. 3).

\section{Predictive factors for acute GVHD}

Univariate analysis showed that age less than 40 years old $(p=0.077)$, lower frequencies of post-HSCT $\mathrm{CD}^{+} \mathrm{T}$ cells $(\leq 5.8 \%$ per $\mathrm{MNC})$, iNKT cells $(\leq 0.027 \%$ per $\mathrm{MNC}$ ), and M-MDSCs ( $\leq 0.27 \%$ per $\mathrm{MNC})$, and higher frequency of I-MDSCs $(>0.11 \%$ per $\mathrm{MNC})$ were potential factors that increase the incidence of grade III $\sim$ IV acute GVHD (Supplementary Table 1). Multivariate analyses showed that only post-HSCT iNKT cells (hazard ratio (HR), 0.453, 95\% CI, 0.091 0.844, p=0.024) and post-HSCT M-MDSCs (HR, 0.271, 95\% CI, 0.078 0.937, $\mathrm{p}=0.039)$ were independent factors affecting the incidence of grade III $\sim$ IV acute GVHD (Table 2). The factor of donor type was intentionally included in multivariate analysis regardless of $\mathrm{p}$ value in univariate analysis. It did not affect incidence of grade III $\sim$ IV acute GVHD. We analyzed the additional factors causing the changes in iNKT cells and M-MDSCs in Supplementary Table 2. No other factors among post-HSCT immune cells were identified that affected grade II $\sim$ IV acute GVHD (data not shown).

\section{Impact of post-HSCT iNKT cells and M-MDSCs on survival outcomes and acute GVHD}

Effect of the two immune cell populations that were critical for grade III $\sim$ IV acute GVHD on conventional transplant outcomes was assessed (Table 3). Apart from significant impacts of post-HSCT iNKT cells and $M$ MDSCs on grade III IV acute GVHD, either lower frequency of iNKT cells or higher frequency of M-MDSCs had a trend of higher probability of relapse (for iNKT cells, $13.0 \%$ vs. $0.7 \%, \mathrm{p}=0.08$; for $\mathrm{M}$-MDSCs, $3.5 \%$ vs. $13.8 \%, \mathrm{p}=0.059)$. Except for incidence of relapse, the two 


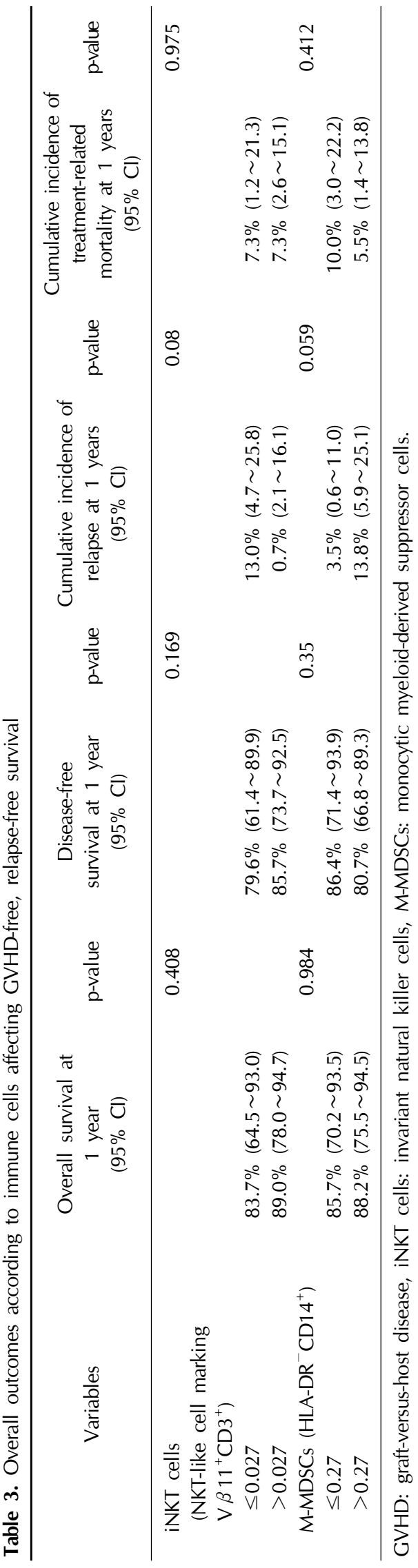

subtypes of immune cells did not significantly affect the other survival outcomes including OS, DFS, and incidence of TRM.

Next, we analyzed impact of combination of post-transplant iNKT cells and M-MDSCs on grade III IV acute GVHD and survival outcomes. Combination of higher frequencies of iNKT cells and M-MDSCs was associated with lower incidence of grade III IV acute GVHD compared to those of lower frequencies of iNKT cells and M-MDSCs [2.8\% (95\% CI, $0.2 \sim 12.6)$ vs. $31.6 \%$ (95\% CI, $12.4 \sim 52.9)$, $\mathrm{p}=0.002$ ] (Fig. 1). Whereas any combination did not show significant impact on OS $(p=0.696)$, DFS $(p=0.418)$, or incidence of TRM ( $p=0.282$ ) (Fig. 2A, B, D), the combination with lower frequency of iNKT cell and higher frequency of M-MDSCs showed significant higher probability of relapse compared to those with higher frequency of iNKT cell and lower frequency of M-MDSCs [20.9\% ( $95 \% \mathrm{CI}, 12.4 \sim 52.9)$ vs. $2.9 \%$ (95\% CI, $0.2 \sim 12.6), \mathrm{p}=$ 0.011] (Fig. 2C).

\section{Discussion}

We showed that two immune cell populations, iNKT cells and M-MDSCs, expanded shortly after clinical allo-HSCT were associated with grade III $\sim$ IV acute GVHD and leukemia relapse. Higher frequency of iNKT cells in the peripheral blood of the patients post-transplantation was associated with a reduction in acute GVHD risk, importantly with a trend in reduced leukemia relapse. And the recovery of circulating M-MDSCs also was more critical to reduced occurrence of acute GVHD but there was a trend in increased leukemia relapse. Patients with lower recovery of both iNKT cells and M-MDSCs had a significantly increased grade III $\sim$ IV acute GVHD, whereas interestingly the combination of higher iNKT cells and lower M-MDSCs correlated with increase enhancement of GVL effect after allo-HSCT. Therefore, potency of iNKT cells after allo-HSCT is likely to be dependent on the expansion of M-MDSCs in the context to the regulation of GVHD and GVL effec. iNKT cells are a rare subset of $T$ lymphocytes which are characterized by the coexpression of NK and T cell markers. They express a $\mathrm{T}$ cell receptor (TCR) which is semi-invariant ( $\mathrm{V} \alpha 24 \mathrm{~J} \alpha 18$ typically pairing with $\mathrm{V} \beta 11$ in humans) and which recognizes glycolipid antigens presented by the non-polymorphic MHC Class I-like molecule CD1d with high affinity (23). Despite their rarity, iNKT cells exert potent immunomodulatory functions bridging the innate and adaptive immune systems by rapidly producing large amounts of cytokines and chemokines. This results either in en- 


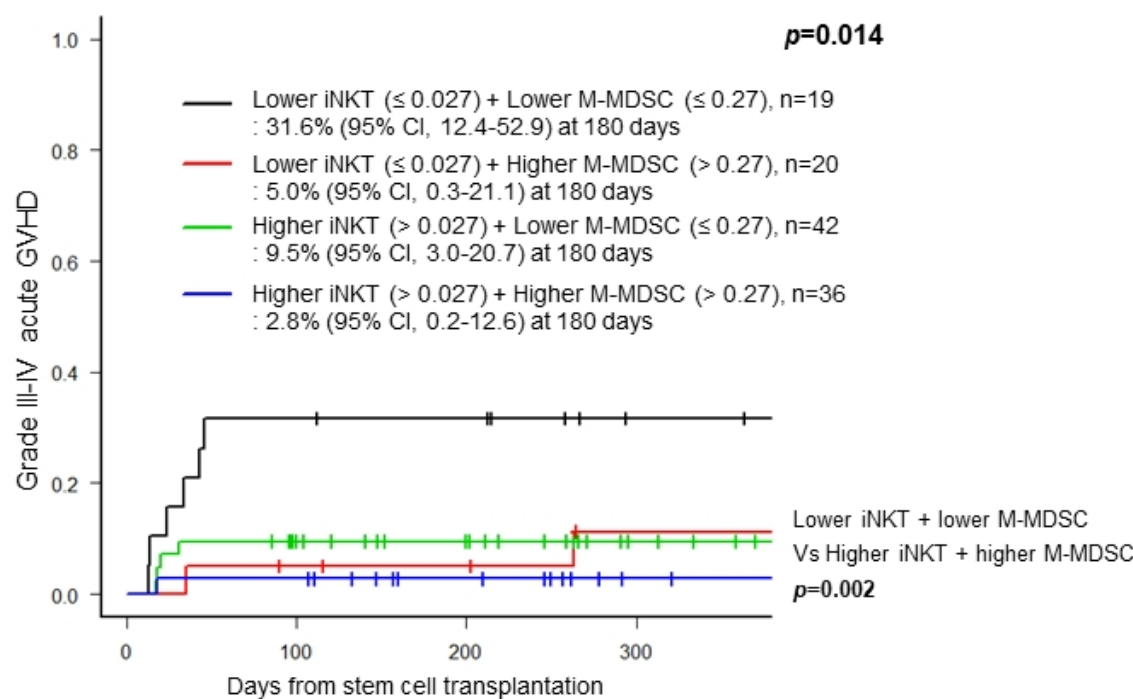

Number at risk

\begin{tabular}{lllll}
\hline Lower iNKT + lower M-MDSC & 19 & 14 & 12 & 6 \\
Lower iNKT + higher M-MDSC & 20 & 16 & 13 & 10 \\
Higher iNKT + lower M-MDSC & 42 & 35 & 27 & 14 \\
Higher iNKT + higher M-MDSC & 36 & 33 & 25 & 17 \\
\hline
\end{tabular}

Fig. 1. Cumulative incidence of grade III-IV acute GVHD accoring to the combinations of frequency of invariant natural killer cells (iNKT) and monocytic myeloid-derived suppressor cell population (M-MDSC). Black line, lower iNKT $(\leq 0.027 \%)$ + lower M-MDSC ( $\leq 0.27 \%$ ), $\mathrm{n}=19$; Red line, lower iNKT ( $\leq$ $0.027 \%)+$ higher M-MDSC (> $0.27 \%), \mathrm{n}=20$; Green line, higher iNKT (> 0.027\%) + lower M-MDSC $(\leq 0.27 \%), n=42$; Blue line, higher iNKT $(>0.027 \%)+$ lower M-MDSC (>0.27\%), n=36. hanced immune responses (i.e., defense against pathogens, immunosurveillance in cancer) via the production of Th1 cytokines such as interferon (IFN)- $\gamma$ or in suppression of autoimmune and alloimmune reactions by the production of interleukin (IL)-4 and IL-10 (24, 25). First human report delineating iNKT reconstitution following allo-HSCT demonstrated a correlation between increased peripheral blood iNKT cell count and reduced acute and chronic GVHD (26). Early post-transplantation iNKT recovery such as iNKT/T ratio at day 15 predicted acute GVHD and OS (27). It has been reported that recovery of iNKT cells is also associated with enhanced GVL effect $(28,29)$, suggesting that monitoring of iNKT cell reconstitution post-transplant and adoptively transferring donor iNKT cells may be a method by which relapse could be prevented (30).

MDSCs, morphologically a mixture of monocytic and granulocytic cells, accumulate in large numbers during many pathologic conditions, including cancer, infectious diseases, trauma, or sepsis. They are characterized by their myeloid origin, immature state, and most importantly by their potent ability to suppress different aspects of immune responses, especially T-cell proliferation and cytokine production (31). We previously showed that two main subgroups of MDSCs differentially expanded shortly after clinical allo-HSCT and increased expansion of M-MDSCs was more critical to the occurrence of early infections, 1-year TRM and lower survival (32).
In this study, we demonstrate the possibility that circulating iNKT cells cooperate with M-MDSCs in protecting patients with acute leukemia against the development of grade III $\sim$ IV acute GVHD and leukemia relapse after allo-HSCT. Several studies have proposed a link between iNKT cells and MDSCs. In mice, MDSC activation was dependent on the presence of host iNKT cells. The conditioning regimen polarized the host iNKT cells toward IL-4 secretion, and MDSC activation was dependent on IL-4 (33). NKT cell activation via glycolipid-loaded dendritic cells decreased the frequency and immunosuppressive activity of MDSCs in tumor-resected mice. In vitro, NKT cells were resistant to the immunosuppressive effects of MDSCs and were able to reverse the inhibitory effects of MDSCs on $\mathrm{T}$ cell proliferation (34). iNKT cells have been shown to regulate MDSC-mediated immune suppression during viral infection (35), suggesting that the interaction between iNKT cells and M-MDSCs on leukemia-associated immunosuppression in the context of allo-HSCT requires further investigation.

We acknowledge that the single institution and measurements only at one point are inherent flaws of our study, although these limitations are mitigated to some degree by the relatively large size of the cohort. Our measurement time point was supported in analyses looking at the recovery of innate immunity over time, which both subsets of immune cells, iNKT cells and M-MDSCs maximally recovered between 2 and 4 weeks, well before the 
(A)

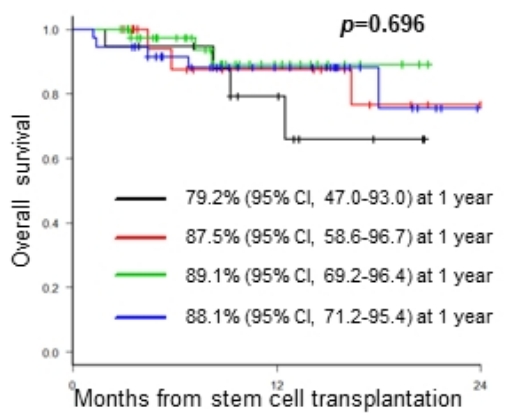

\begin{tabular}{llll}
\multicolumn{1}{c}{ Number at risk } & & & \\
\hline Lower iNKT + lower M-MDSC & 19 & 10 & 6 \\
Lower iNKT + higher M-MDSC & 20 & 15 & 8 \\
Higher iNKT + lower M-MDSC & 42 & 21 & 21 \\
Higher iNKT + higher M-MDSC & 36 & 27 & 7 \\
\hline
\end{tabular}

(C)

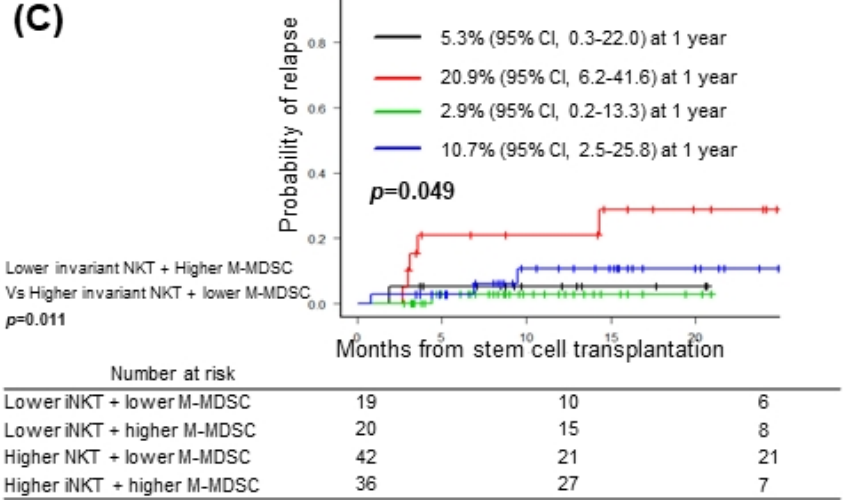

(B)

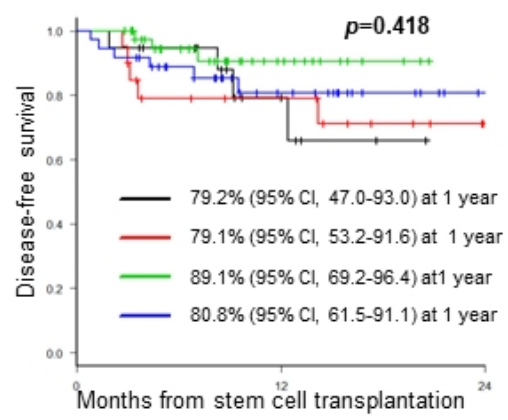

\begin{tabular}{cccl}
\multicolumn{1}{c}{ Number at risk } & & & \\
\hline Lower iNKT + lower M-MDSC & 19 & 10 & 6 \\
Lower iNKT + higher M-MDSC & 20 & 15 & 8 \\
Higher iNKT + lower M-MDSC & 42 & 21 & 21 \\
Higher iNKT + higher M-MDSC & 36 & 19 & 5 \\
\hline
\end{tabular}

(D)

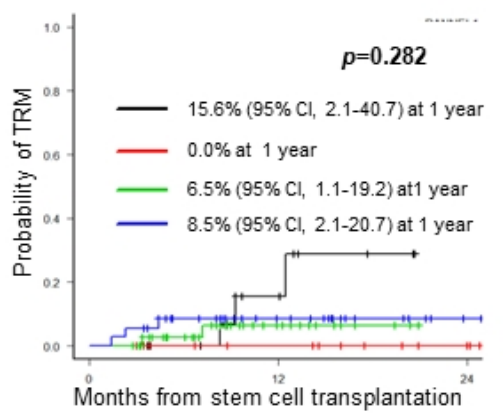

\begin{tabular}{llll}
\multicolumn{1}{c}{ Number at risk } & & & \\
\hline Lower iNKT + lower M-MDSC & 19 & 8 & 1 \\
Lower iNKT + higher M-MDSC & 20 & 12 & 5 \\
Higher iNKT + lower M-MDSC & 42 & 12 & 1 \\
Higher iNKT + higher M-MDSC & 36 & 16 & 2 \\
\hline
\end{tabular}

- Lower INKT + Lower M-MDSC

- Lower iNKT + Higher M-MDSC

- Higher INKT + Lower M-MDSC

- Higher iNKT + Higher M-MDSC

Fig. 2. Major outcomes accoring to the combinations of frequency of invariant natural killer cells (iNKT) and monocytic myeloid-derived suppressor cell population (M-MDSC). Black line, lower iNKT $(\leq 0.027 \%)+$ lower M-MDSC $(\leq 0.27 \%), n=19$; Red line, lower iNKT $(\leq 0.027 \%)+$ higher M-MDSC $(>0.27 \%), \mathrm{n}=20$; Green line, higher iNKT $(>0.027 \%)+$ lower M-MDSC $(\leq 0.27 \%), \mathrm{n}=42 ; \mathrm{Blue}$ line, higher iNKT $(>0.027 \%)+$ lower M-MDSC $(>0.27 \%), n=36$. (A) Overall survival, (B) disease-free survival, (C) cumulative incidence of relaspse, and (D) cumualtive incidence of transplant-related mortality (TRM).

recovery of adaptive immunity (36). In the TCR $\alpha$ chain of human iNKT cells, the $\mathrm{V} \alpha 24$ segment is joined with $\mathrm{J} \alpha 18$ in a germ-line configuration, resulting in an invariant CDR3 loop encoded by the mature TCR $\alpha$ chain (37). This $\alpha$ chain pairs with a restricted range of randomly rearranged $\mathrm{V} \beta$ chains, with $\mathrm{V} \beta 11$ being the most prominent in humans (38). In our study, iNKT cells were identified with the expression of CD3, CD56 and antiTCRV $\beta$ 11. Non-invariant and non-CD1d-restricted V $\alpha 24^{+} \mathrm{T}$ cells can also pair with $\mathrm{V} \beta 11$, and contribute to the $\mathrm{V} \alpha 24^{+} / \mathrm{V} \beta 11^{+}$subpopulation. This could lead to an overestimation of iNKT cell number, especially in individuals with decreased number of iNKT cells. Of note, in our study significant change in TRM, DFS or OS was not noted in spite of reduced acute GVHD and leukemia relapse. Our observations should be interpreted with some caution until it is validated in a large independent cohort with long-term follow-up.

In summary, iNKT cells and M-MDSCs in peripheral blood early after transplantation can be attractive biomarkers to predict allo-HSCT outcomes including acute GVHD and leukemia relapse. Although rare in number, circulating iNKT cells and M-MDSCs may represent the most versatile and critical cell population for suppressing acute GVHD. In particular, iNKT cells can thus be harnessed to suppress undesirable allo-immune responses while maintaining desirable GVL effect together with reduced M-MDSCs. 


\section{Acknowledgments}

This research was supported by a grant from the Korea Health Technology R\&D Project through the Korea Health Industry Development Institute (KHIDI), funded by the Ministry of Health \& Walfare, Republic of Korea (\#HI16C0047).

\section{Potential Conflict of Interest}

The authors have no conflicting financial interest.

\section{Supplementary Materials}

Supplementary data including two tables and three figures can be found with this article online at http://pdf. medrang.co.kr/paper/pdf/IJSC/IJSC-11-s18094.pdf.

\section{References}

1. Janikova A, Bortlicek Z, Campr V, Kopalova N, Benesova K, Hamouzova M, Belada D, Prochazka V, Pytlik R, Vokurka S, Pirnos J, Duras J, Mocikova H, Mayer J, Trneny $M$. The incidence of biopsy-proven transformation in follicular lymphoma in the rituximab era. A retrospective analysis from the Czech Lymphoma Study Group (CLSG) database. Ann Hematol 2018;97:669-678

2. Stelljes M, Krug U, Beelen DW, Braess J, Sauerland MC, Heinecke A, Ligges S, Sauer T, Tschanter P, Thoennissen GB, Berning B, Kolb HJ, Reichle A, Holler E, Schwerdtfeger R, Arnold R, Scheid C, Müller-Tidow C, Woermann BJ, Hiddemann W, Berdel WE, Büchner T. Allogeneic transplantation versus chemotherapy as postremission therapy for acute myeloid leukemia: a prospective matched pairs analysis. J Clin Oncol 2014;32:288296

3. Kim N, Cho SG. New strategies for overcoming limitations of mesenchymal stem cell-based immune modulation. Int J Stem Cells 2015;8:54-68

4. Koreth J, Schlenk R, Kopecky KJ, Honda S, Sierra J, Djulbegovic BJ, Wadleigh M, DeAngelo DJ, Stone RM, Sakamaki H, Appelbaum FR, Döhner H, Antin JH, Soiffer RJ, Cutler C. Allogeneic stem cell transplantation for acute myeloid leukemia in first complete remission: systematic review and meta-analysis of prospective clinical trials. JAMA 2009;301:2349-2361

5. Bourlon C, Lacayo-Leñero D, Inclán-Alarcón SI, Demichelis-Gómez R. Hematopoietic stem cell transplantation for adult Philadelphia-negative acute lymphoblastic leukemia in the first complete remission in the era of minimal residual disease. Curr Oncol Rep 2018;20:36 [Epub]. doi: 10.1007/s11912-018-0679-9

6. Beatty PG, Clift RA, Mickelson EM, Nisperos BB, Flournoy N, Martin PJ, Sanders JE, Stewart P, Buckner CD, Storb R, Thomas DE, Hansen JA. Marrow transplantation from related donors other than HLA-identical siblings. N Engl J Med 1985;313:765-771

7. Remberger M, Persson U, Hauzenberger D, Ringdén O. An association between human leucocyte antigen alleles and acute and chronic graft-versus-host disease after allogeneic haematopoietic stem cell transplantation. Br J Haematol 2002;119:751-759

8. Weisdorf D, Hakke R, Blazar B, Miller W, McGlave P, Ramsay N, Kersey J, Filipovich A. Risk factors for acute graft-versus-host disease in histocompatible donor bone marrow transplantation. Transplantation 1991;51:1197-1203

9. Urbano-Ispizua A, Rozman C, Pimentel P, Solano C, de la Rubia J, Brunet S, Pérez-Oteyza J, Ferrá C, Zuazu J, Caballero D, Bargay J, Carvalhais A, Díez JL, Espigado I, Alegre A, Rovira M, Campilho F, Odriozola J, Sanz MA, Sierra J, García-Conde J, Montserrat E; Spanish Group for Allogeneic Peripheral Blood Transplantation (Grupo Español de Trasplante Hemopoyético) and Instituto Português de Oncologia-Porto. Risk factors for acute graft-versus-host disease in patients undergoing transplantation with CD34+ selected blood cells from HLA-identical siblings. Blood 2002;100:724-727

10. Goulmy E, Schipper R, Pool J, Blokland E, Falkenburg JH, Vossen J, Gratwohl A, Vogelsang GB, van Houwelingen HC, van Rood JJ. Mismatches of minor histocompatibility antigens between HLA-identical donors and recipients and the development of graft-versus-host disease after bone marrow transplantation. N Engl J Med 1996;334:281-285

11. Kollman C, Howe CW, Anasetti C, Antin JH, Davies SM, Filipovich AH, Hegland J, Kamani N, Kernan NA, King R, Ratanatharathorn V, Weisdorf D, Confer DL. Donor characteristics as risk factors in recipients after transplantation of bone marrow from unrelated donors: the effect of donor age. Blood 2001;98:2043-2051

12. Cutler C, Giri S, Jeyapalan S, Paniagua D, Viswanathan A, Antin JH. Acute and chronic graft-versus-host disease after allogeneic peripheral-blood stem-cell and bone marrow transplantation: a meta-analysis. J Clin Oncol 2001;19: 3685-3691

13. Jagasia M, Arora M, Flowers ME, Chao NJ, McCarthy PL, Cutler CS, Urbano-Ispizua A, Pavletic SZ, Haagenson MD, Zhang MJ, Antin JH, Bolwell BJ, Bredeson C, Cahn JY, Cairo M, Gale RP, Gupta V, Lee SJ, Litzow M, Weisdorf DJ, Horowitz MM, Hahn T. Risk factors for acute GVHD and survival after hematopoietic cell transplantation. Blood 2012;119:296-307

14. Wermke M, Maiwald S, Schmelz R, Thiede C, Schetelig J, Ehninger G, Bornhäuser M, Wassmuth R. Genetic variations of interleukin-23R $(1143 \mathrm{~A}>\mathrm{G})$ and BPI (A645G), but not of NOD2, are associated with acute graft-versus-host disease after allogeneic transplantation. Biol Blood Marrow Transplant 2010;16:1718-1727

15. Kim HT, Frederick D, Armand P, Andler E, Kao G, Cutler C, Koreth J, Alyea EP 3rd, Antin JH, Soiffer RJ, Ritz J, Ho VT. White blood cell recovery after allogeneic hematopoietic cell transplantation predicts clinical outcome. Am J Hematol 2014;89:591-597 
16. Lucchini G, Perales MA, Veys P. Immune reconstitution after cord blood transplantation: peculiarities, clinical implications and management strategies. Cytotherapy 2015; 17:711-722

17. Gyurkocza B, Sandmaier BM. Conditioning regimens for hematopoietic cell transplantation: one size does not fit all. Blood 2014;124:344-353

18. Lee S, Kim DW, Cho BS, Yoon JH, Shin SH, Yahng SA, Lee SE, Eom KS, Kim YJ, Chung NG, Kim HJ, Min CK, Lee JW, Min WS, Park CW. Impact of minimal residual disease kinetics during imatinib-based treatment on transplantation outcome in Philadelphia chromosome-positive acute lymphoblastic leukemia. Leukemia 2012;26:2367-2374

19. Park SS, Kim HJ, Min KI, Min GJ, Jeon YW, Yoon JH, Yahng SA, Shin SH, Lee SE, Cho BS, Eom KS, Kim YJ, Lee S, Min CK, Cho SG, Kim DW, Lee JW, Min WS. Prognostic prediction model for second allogeneic stem-cell transplantation in patients with relapsed acute myeloid leukemia: single-center report. Clin Lymphoma Myeloma Leuk 2018;18:e167-e182

20. Bronte V, Brandau S, Chen SH, Colombo MP, Frey AB, Greten TF, Mandruzzato S, Murray PJ, Ochoa A, Ostrand-Rosenberg S, Rodriguez PC, Sica A, Umansky V, Vonderheide RH, Gabrilovich DI. Recommendations for myeloid-derived suppressor cell nomenclature and characterization standards. Nat Commun 2016;7:12150 [Epub]. doi: $10.1038 /$ ncomms12150

21. Sorror ML, Maris MB, Storb R, Baron F, Sandmaier BM, Maloney DG, Storer B. Hematopoietic cell transplantation (HCT)-specific comorbidity index: a new tool for risk assessment before allogeneic HCT. Blood 2005;106:2912-2919

22. Harris AC, Young R, Devine S, Hogan WJ, Ayuk F, Bunworasate U, Chanswangphuwana C, Efebera YA, Holler E, Litzow M, Ordemann R, Qayed M, Renteria AS, Reshef R, Wölfl M, Chen YB, Goldstein S, Jagasia M, Locatelli F, Mielke S, Porter D, Schechter T, Shekhovtsova Z, Ferrara JL, Levine JE. International, multicenter standardization of acute graft-versus-host disease clinical data collection: a report from the mount sinai acute GVHD international consortium. Biol Blood Marrow Transplant 2016;22:4-10

23. Lantz O, Bendelac A. An invariant $T$ cell receptor alpha chain is used by a unique subset of major histocompatibility complex class I-specific CD4+ and CD4-8- T cells in mice and humans. J Exp Med 1994;180:1097-1106

24. Bendelac A, Savage PB, Teyton L. The biology of NKT cells. Annu Rev Immunol 2007;25:297-336

25. Brennan PJ, Brigl M, Brenner MB. Invariant natural killer T cells: an innate activation scheme linked to diverse effector functions. Nat Rev Immunol 2013;13:101-117

26. Haraguchi K, Takahashi T, Hiruma K, Kanda Y, Tanaka Y, Ogawa S, Chiba S, Miura O, Sakamaki H, Hirai H. Recovery of Valpha24+ NKT cells after hematopoietic stem cell transplantation. Bone Marrow Transplant 2004; 34:595-602

27. Rubio MT, Moreira-Teixeira L, Bachy E, Bouillié M,
Milpied P, Coman T, Suarez F, Marcais A, Sibon D, Buzyn A, Caillat-Zucman S, Cavazzana-Calvo M, Varet B, Dy M, Hermine O, Leite-de-Moraes M. Early posttransplantation donor-derived invariant natural killer T-cell recovery predicts the occurrence of acute graft-versus-host disease and overall survival. Blood 2012;120:2144-2154

28. Beziat V, Nguyen S, Exley $M$, Achour A, Simon T, Chevallier P, Sirvent A, Vigouroux S, Debré P, Rio B, Vieillard V; French Minicord Study Group. Shaping of iNKT cell repertoire after unrelated cord blood transplantation. Clin Immunol 2010;135:364-373

29. de Lalla C, Rinaldi A, Montagna D, Azzimonti L, Bernardo ME, Sangalli LM, Paganoni AM, Maccario R, Di CesareMerlone A, Zecca M, Locatelli F, Dellabona P, Casorati G. Invariant NKT cell reconstitution in pediatric leukemia patients given HLA-haploidentical stem cell transplantation defines distinct CD4+ and CD4- subset dynamics and correlates with remission state. J Immunol 2011;186:4490-4499

30. Dellabona P, Casorati G, de Lalla C, Montagna D, Locatelli F. On the use of donor-derived iNKT cells for adoptive immunotherapy to prevent leukemia recurrence in pediatric recipients of HLA haploidentical HSCT for hematological malignancies. Clin Immunol 2011;140:152-159

31. Youn JI, Gabrilovich DI. The biology of myeloid-derived suppressor cells: the blessing and the curse of morphological and functional heterogeneity. Eur J Immunol 2010; 40:2969-2975

32. Lee SE, Lim JY, Kim TW, Jeon YW, Yoon JH, Cho BS, Eom KS, Kim YJ, Kim HJ, Lee S, Cho SG, Kim DW, Lee JW, Min WS, Shin DM, Choi EY, Min CK. Matrix metalloproteinase-9 in monocytic myeloid-derived suppressor cells correlate with early infections and clinical outcomes in allogeneic hematopoietic stem cell transplantation. Biol Blood Marrow Transplant 2018;24:32-42

33. Hongo D, Tang X, Baker J, Engleman EG, Strober S. Requirement for interactions of natural killer $\mathrm{T}$ cells and myeloid-derived suppressor cells for transplantation tolerance. Am J Transplant 2014;14:2467-2477

34. Gebremeskel S, Clattenburg DR, Slauenwhite D, Lobert L, Johnston B. Natural killer T cell activation overcomes immunosuppression to enhance clearance of postsurgical breast cancer metastasis in mice. Oncoimmunology 2015;4 [Epub]. doi: 10.1080/2162402x.2014.995562

35. De Santo C, Salio M, Masri SH, Lee LY, Dong T, Speak AO, Porubsky S, Booth S, Veerapen N, Besra GS, Gröne HJ, Platt FM, Zambon M, Cerundolo V. Invariant NKT cells reduce the immunosuppressive activity of influenza A virus-induced myeloid-derived suppressor cells in mice and humans. J Clin Invest 2008;118:4036-4048

36. Guan Q, Blankstein AR, Anjos K, Synova O, Tulloch M, Giftakis A, Yang B, Lambert P, Peng Z, Cuvelier GD, Wall DA. Functional myeloid-derived suppressor cell subsets recover rapidly after allogeneic hematopoietic stem/progenitor cell transplantation. Biol Blood Marrow Transplant 2015;21:1205-1214

37. Porcelli S, Yockey CE, Brenner MB, Balk SP. Analysis of 
T cell antigen receptor (TCR) expression by human peripheral blood CD4-8- alpha/beta $\mathrm{T}$ cells demonstrates preferential use of several $\mathrm{V}$ beta genes and an invariant TCR alpha chain. J Exp Med 1993;178:1-16
38. Dellabona P, Padovan E, Casorati G, Brockhaus M, Lanzavecchia A. An invariant V alpha 24-J alpha Q/V beta $11 \mathrm{~T}$ cell receptor is expressed in all individuals by clonally expanded CD4-8- T cells. J Exp Med 1994;180:1171-1176 